\title{
On the variability of benthic foraminiferal species of the genus Pleurostomella in the Tethys
}

\begin{abstract}
Twenty small benthic foraminiferal species of the Rotaliid genus Pleurostomella are common in the late Cretaceous and Paleogene from some Tethyan localities: North Atlantic (USA, Mexico, Caribbean), Europe (France, Poland, Italy, Hungaria, Bulgaria, North Sea), North Africa (Tunisia, Egypt), Southwest Asia (Iraq, UAE), Indian Ocean (Pakistan) and Southern Ocean. Seventeen well-known diagnostic species are: Pleurostomella acuta, P. alternans, P. austinana, P. bellardii, P. brevis, P. clavata, P. cubensis, P. eocaena, P. incrassata, $P$. naranjoensis, $P$. nitida, $P$. nuttalli, $P$. obtusa, P. paleocenica, $P$. subnodosa, $P$. velascoensis, $P$. watersi. Moreover, three other species of Pleurostomella are believed here to be new: (1) the Maastrichtian P. osmani n. sp. is recorded from Abu Zenima section, east Gulf of Suez, west central Sinai, northern Egypt, (2) the Paleocene P. plummerae n. sp. was recorded from the Midway Formation in Texas (USA), and (3) the Eocene P. haquei n. sp. was recorded from Quetta District, West Pakistan.
\end{abstract}

Keywords: benthic foraminifera, Pleurostomella, cretaceous, paleogene, Tethys
Volume 7 Issue 3 - 2019

\author{
Haidar Salim Anan \\ Emeritus Professor of stratigraphy and micropaleontology, Al- \\ Azhar University, Palestine
}

Correspondence: Haidar Salim Anan, Emeritus Professor of stratigraphy and micropaleontology,Al-Azhar University, Gaza P. O. Box I 126, Palestine, Email profanan@gmail.com

Received: April 18, 2019 | Published: June 26, 2019

\section{Introduction}

The rich and diverse late Cretaceous-Paleogene benthic foraminiferal assemblages from Tethys include different species of the Rotaliid genus Pleurostomella (early biserially alternating arrangement chambers, but later uniserial and terminal aperture with or without tooth). The paleontological occurrence of twenty species belonging to the genus Pleurostomella has been reported from many localities in the Tethys (Figure 1\&2). The author has examined many representatives of this genus, which has different length and width, cuneate test or rounded initial periphery, elliptical or oval-shape terminal or subterminal aperture with overhanging hood, with or without simple or bifid apertural tooth. As a whole this taxa are rarely described in the micropaleontological literature, that's why this study is dedicated, and the intent of this study is to bring together many data scattered in the literature under a unifying theme, and to detect its paleontology, stratigraphy, paleobathymetry and paleogeographic distribution of them in the Tethys.

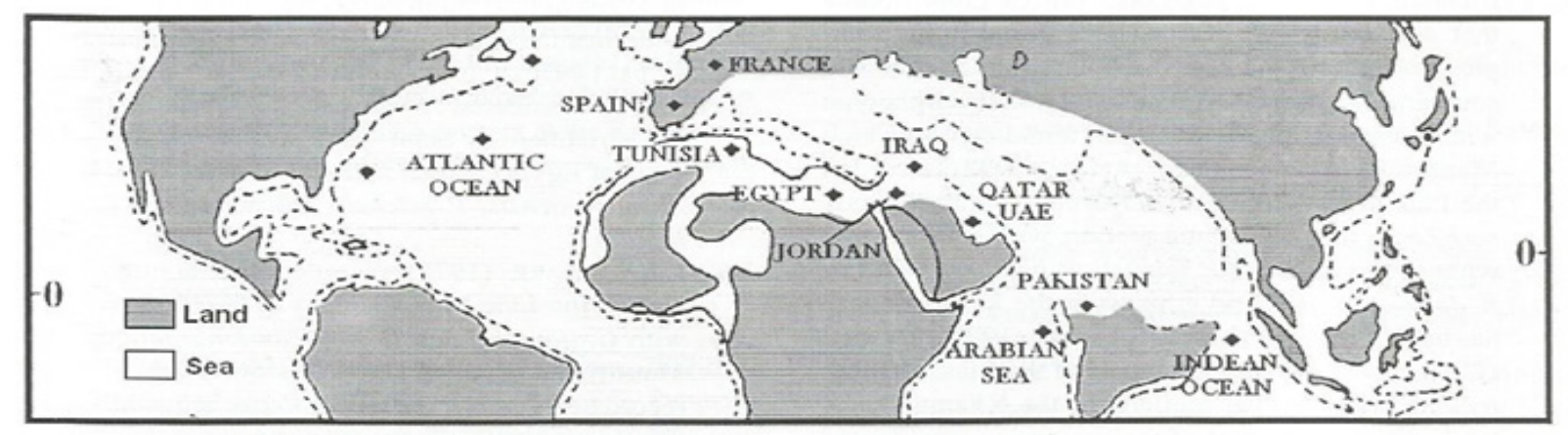

Figure I The paleogeographic map of the terminal Cretaceous showing some Tethyan localities, from west to east: North Atlantic (USA, Mexico, Caribbean), Europe (France, Italy, Bulgaria, Hungaria), Northeast Africa (Tunisia, Egypt), Southwest Asia (Iraq, UAE) and Indian Ocean (Pakistan), after Anan (2012).

\section{Systematic paleontology}

The taxonomy of the identified species follows that of Loeblich $\&$ Tappan $^{1}$ and the illustrated taxa have been shown in Plates $1 \& 2$.

Order Foraminiferida Eichwald, 1830

Suborder Rotaliina Delage \& Hérouard, 1896

Superfamily Pleurostomellacea Reuss ${ }^{2}$

Family Pleurostomellidae Reuss ${ }^{2}$

Subfamily Pleurostomellinae Reuss ${ }^{2}$
Genus Pleurostomella Reuss ${ }^{2}$

Type Species Dentalina subnodosa Reuss ${ }^{2}$

Pleurostomella acuta Hantken, ${ }^{3}$ (Pl. 1, fig. 1)

1875 Pleurostomella acuta Hantken, ${ }^{3}$ p. 37, pl. 13, fig. 18.

1975 Pleurostomella acuta; Proto Decima \& De Biase, ${ }^{4}$ p. 96, pl. 3, fig. 7.

1986 Pleurostomella acuta; Hulsbos, ${ }^{5}$ p. 531, pl. 5, fig. 11.

2000 Pleurostomella acuta; Sztrákos, ${ }^{6}$ p. 146. 
2007 Pleurostomella acuta; Ozsvărt, 7 p. 69, pl. 8, figs. 9-11.

2011 Pleurostomella acuta; Mohan et al., ${ }^{8}$ p. 60, pl. 9, fig. 9.

2012 Pleurostomella acuta; Hayward et al., ${ }^{9}$ p. 227, pl. 35, figs. $9-18$. 13.

2013 Pleurostomella acuta; Alegret \& Thomas, ${ }^{10}$ p. 44, pl. 1, fig.

Remarks: Test loosely biserial early stage, oval in outline and circular in cross-section, length approximately two times maximum width, chambers increasing gradually in size and final pair of chambers extremely inflated, sutures barely visible, slightly depressed and strongly curved, wall calcareous hyaline smooth and finely perforated, aperture terminal with large oval opening of final chamber. Hayward et al., ${ }^{9}$ noted that P. acuta is more inflated than P. incrassata. It was recorded from the Cretaceous-Paleogene transition in Southern Ocean, Paleocene-early Eocene from Italy, early-middle Eocene from France, but middle-late Eocene from Hungaria. After Hayward et al., ${ }^{9}$

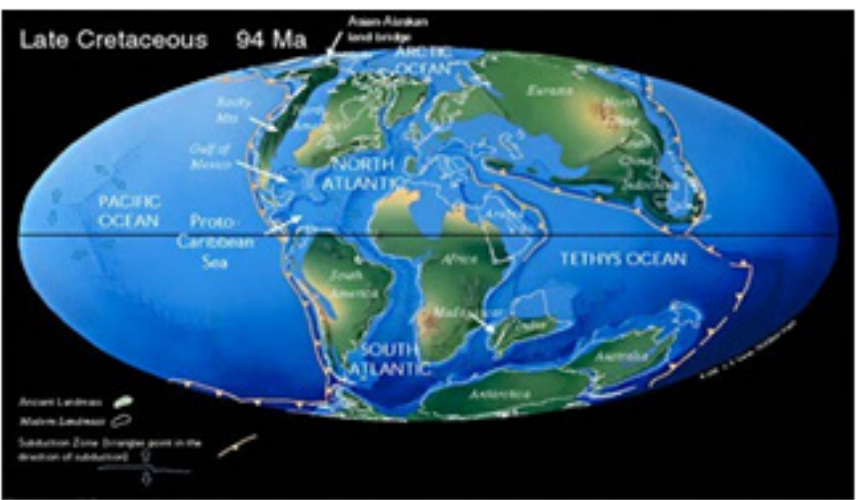

the paleo-bathymetric distribution of $P$. acuta in present-day depth ranges of sites: lower bathyal-middle abyssal (1200-4000 m).

Pleurostomella alternans Schwager, ${ }^{11}$ (Pl. 1, fig. 2a-c) 80.

1866 Pleurostomella alternans Schwager, ${ }^{11}$ p. 238, pl. 6, figs. 79,

1927 Pleurostomella alternans; Plummer, ${ }^{12}$ p. 69, pl. 4, fig. 2a (non fig. 2b).

2000 Pleurostomella alternans; Sztrákos, ${ }^{6}$ p. 146.

2007 Pleurostomella alternans; Ozsvărt, ${ }^{7}$ p. 70, pl. 8, fig. 12.

2007 Pleurostomella alternans; Hayward et al., ${ }^{13}$ p. 8, fig. 2.4.

2011 Pleurostomella alternans; Mohan et al., ${ }^{8}$ p. 60, pl. 9, fig. 10.

2012 Pleurostomella alternans; Hayward et al., ${ }^{9}$ p. 228, pl. 36, figs. 9-15.

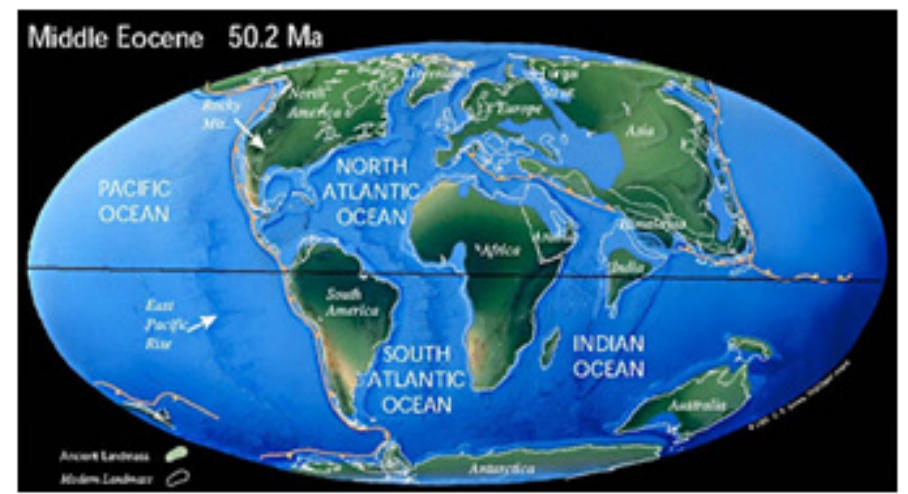

Figure 2 The paleogeographic distribution of the Tethys (left) in the Late Cretaceous ( $94 \mathrm{Ma})$ to (right) Middle Eocene (50.2 Ma), showing some localities in the Tethys, from west to east: North Atlantic, Europe, Northeast Africa, Southwest Asia and Indian Ocean.

Remarks: Plummer recorded two forms (1927, pl. 4, figs. 2a,b) belonging to the species of Schwager. Plummer's form (2a) belongs here to Schwager's species, while form (2b) is treated here to a different species (see below). P. alternans has an elongate smooth test tapering very bluntly toward the aboral extremity with 7-8 biserial arrangement of chambers but later uniserial, aperture highly arched and vertical with the sharply pointed tooth. Hayward et al., ${ }^{9}$ noted that P. acuminata Cushman (1922) commonly co-occurs with $P$. alternans, from which it differs by its elongate rather than squat chambers. They also added that the original Novara Expedition foraminiferal specimens described by Schwager, ${ }^{11}$ including P. alternans, have been lost from the Museum of Natural History, Vienna, during wartime upheavals. It was recorded from Paleocene-Eocene of France, Italy and USA. The age of this species was indicated by Schwager a younger or middle Paleogene age, middle-upper Eocene from Hungaria, and Eocene of France. Halkyard (after Plummer, 1927) reports it from the upper Eocene of Biarritz, but upper portion of the Paleocene Midway Formation in Texas, USA. After Hayward et al., ${ }^{9}$ the paleo-bathymetric distribution of $P$. alternans in present-day depth range of sites: upper bathyal-middle abyssal (400-4000 m).

Pleurostomella austinana Cushman, ${ }^{14}$ (Pl. 1, fig. 3)

1933 Pleurostomella austinana Cushman, ${ }^{14}$ p. 64, pl. 7, fig. 13.
1946 Pleurostomella austinana; Cushman, ${ }^{15}$ p. 131, pl. 54, figs. 19-21.

Remarks: This late Cretaceous has long and slender test with being loosely biserial stage. It was originally recorded from Texas (USA). Hayward et al., ${ }^{9}$ treated this species in the synonym list of $P$. subnodosa (Reuss).

Pleurostomella bellardii Hantken, ${ }^{3}$ (P1. 1, fig. 4)

1883 Pleurostomella bellardii Hantken, ${ }^{3}$ p. 25, pl. 2, fig. 1.

2000 Pleurostomella bellardii; Sztrákos, ${ }^{6}$ p. 167, pl. 5, figs. 12, 13.

Remarks: This middle Eocene species has short test, and the last two chambers occupied about $2 / 3$ of the test size. This species has less width than P. brevis Schwager. Hayward et al., ${ }^{9}$ treated this species in the synonym list of $P$. wadowicensis Grzybowski, 1896.

Pleurostomella brevis Schwager, ${ }^{11}$ (P1. 1, fig. 5)

1866 Pleurostomella brevis Schwager, ${ }^{11}$ p. 239, pl. 6, fig. 81.

1989 Pleurostomella brevis; Hantken, ${ }^{3}$ p. 117, fig. 3D.

2011 Pleurostomella brevis; Mohan et al., ${ }^{8}$ p. 60, pl. 9, figs. 11, 12.

2012 Obesopleurostomella brevis; Hayward et al., ${ }^{9}$ p. 221, pl. 33, figs. 3-8. 
Remarks: This species belongs to Hayward's new genus Obesopleurostomella by Hayward et al., ${ }^{9}$ (which not recorded in Loeblich \& Tappan ${ }^{1}$ ), due to medium-large moderately inflated biserial test, overlapping last two chambers which consists about half the testsize, with small semicircular upper portion aperture and two small teeth. This species has more width and shorter length than another species of P. alternans. After Hayward et al., ${ }^{9}$ the paleobathymetric distribution of this specie in present-day depth range of sites: middle bathyal-middle abyssal (900-4000 m).

Pleurostomella clavata Cushman, ${ }^{16}$ (P1. 1, fig. 6)

1926 Pleurostomella clavata Cushman, ${ }^{16}$ p. 590, pl. 16, fig. 5.

1946 Pleurostomella clavata; Cushman, ${ }^{15}$ p. 132, pl. 54, fig. 25.

1994 Pleurostomella clavata; Bolli et al., ${ }^{17}$ p. 142, fig. 38.2.

Remarks: This Maastrichtian-early Eocene species is distinguished by its tapering initial test than the rounded one in P. brevis of Schwager Hayward et al., ${ }^{9}$ treated this species in the synonym list of $P$. acuta Hantken.

\section{Pleurostomella cubensis Cushman \& Bermudez, ${ }^{18}$ (Pl. 1, fig. 7)}

1937 Pleurostomella alazanensis var. cubensis Cushman \& Bermudez, ${ }^{18}$ p. 17 , pl. 1, figs. 64,65 .

1994 Pleurostomella cubensis; Bolli et al., ${ }^{17}$ p. 142, fig. 38.4-5.

Remarks: This early Eocene species has shorter elongation than $P$. alternans and differs by its diagnostic apertural tooth. Hayward et al.,' treated this species in the synonym list of $P$. alazanensis Cushman.

Pleurostomella eocaena Gümbel, ${ }^{19}$ (Pl. 1, fig. 8)

1868 Pleurostomella eocaena Gümbel ${ }^{19}$ p. 52, pl. 1, fig. 53.

1975 Pleurostomella eocaena; Proto Decima \& De Biase, ${ }^{20}$ p. 96, pl. 3, fig. 6 .

2007 Pleurostomella eocaena; Ozsvărt, ${ }^{7}$ p. 70, pl. 8, fig. 13.

2007 Pleurostomella eocaena; Valchev, ${ }^{21}$ p. 136.

Remarks: Test elongate, loosely biserial, lobulate in outline and circular in cross-section; length approximately three to four times of maximum width; chambers increasing rapidly in size; sutures slightly depressed; wall calcareous, hyaline, smooth, finely perforated; aperture oval opening of final chamber. $P$. alternans Schwager has large, oval aperture contrary to $P$. eocaena Gümbel, ${ }^{19}$ which has much smaller aperture. Hayward et al., ${ }^{9}$ treated this species in the synonym list of P. subnodosa (Reuss). It was recorded in the Paleoceneearly Eocene from Italy and Bulgaria, but middle-late Eocene from Hungaria.

\section{Pleurostomella incrassata Hantken, ${ }^{3}$ (Pl. 1, fig. 9)}

1883 Pleurostomella incrassata Hantken, ${ }^{3}$ p. 25, pl. 1, fig. 4

1975 Pleurostomella incrassata; Proto Decima \& De Biase, ${ }^{20} \mathrm{p}$. 96 , pl. 3 , fig. 5 . 10

1986 Pleurostomella incrassata; Hulsbos et al., 5 p. 531, pl. 5, fig.

2000 Pleurostomella incrassata; Sztrákos, ${ }^{6}$ p. 167, pl. 5, figs. 14, 15 .

2007 Pleurostomella incrassata; Ozsvărt, ${ }^{7}$ p. 70, pl. 8, figs. 15, 16.
2012 Pleurostomella incrassata; Hayward et al., ${ }^{9}$ p. 230 , pl. 37 figs. 16-21, pl. 38, 1-4.

Remarks: Test loosely biserial, lobulate in outline and circular in cross-section, length approximately two to three times of maximum width, pre-final chamber extremely inflated globular and large, inflated final chamber, sutures distinct and strongly depressed, wall calcareous hyaline smooth and finely perforated, aperture small oval opening of final chamber. Hayward et al., ${ }^{9}$ noted that this species has often been referred to P. alternans, but differs in being more distinctly inflated and has less tendency to become staggered uniserial in larger specimens. They also noted that the paleo-bathymetric distribution of late Cretaceous-late Pliocene $P$. incrassata in present-day depth range of sites: lower bathyal-middle abyssal (1200-3600 m).

\section{Pleurostomella haquei Anan, ${ }^{22}$ n. sp. (Pl. 1, fig. 10)}

1960 Pleurostomella n. sp. Haque, ${ }^{23}$ p. 28, pl. 5, fig. 7.

Holotype: Plate 1, fig. 10.

Type locality: KSR (Sor Range), Quetta District, West Pakistan.

Type sample: sample 5, KSR.

Age: middle-late Eocene.

Etymology: In the memory of the late Pakistanian micropaleontologist Mohsenul Haque.

Diagnosis: This species has short and cuneate test, the initial chambers arrangement varying from biserial to nearly uniserial, sutures distinct and depressed, wall calcareous and finely perforate, the last chamber inflated, but the terminal part is broken, fore that the aperture not exist.

Remarks: This Eocene species has erected and elongate test with lax biserial arrangement, and the final uniserial chamber inflated and nearly globular, but the terminal part is unfortunately broken.

Pleurostomella naranjoensis Cushman \& Bermudez, ${ }^{18}$ (P1. 1, fig. 11)

1937 Pleurostomella naranjoensis Cushman \& Bermudez, ${ }^{18}$ p. 16 , pl. 1, figs. 59,60 .

1994 Pleurostomella naranjoensis; Bolli et al., ${ }^{17}$ p. 143, fig. 38.67.

Remarks: This Paleocene-early Eocene species has short test, but more width than $P$. cubensis and its biserial portion has rounded periphery. After Hayward et al. ${ }^{9}$, the holotype of P. naranjoensis has small, incompletely developed aberrant final chambers with small, terminal apertures. They also treated this species in the synonym list of $P$. acuta Hantken. Moreover, they also treated the figured specimen $P$. naranjoensis of Bignot, ${ }^{24}$ (pl. 4, fig. 10) as a junior synonym of $P$. incrassata Hantken.

\section{Pleurostomella nitida Morrow, ${ }^{25}$ (Pl. 1, fig. 12)}

1934 Pleurostomella nitida Morrow, ${ }^{25}$ p. 196, pl. 30, fig. 22.

1946 Pleurostomella nitida; Cushman, ${ }^{15}$ p. 132, pl. 54, fig. 24.

Remarks: This late Cretaceous American species has compressed test, nearly straight sides and tapering initial base, subterminal elliptical without toothed aperture. Hayward et al. ${ }^{9}$ treated this species in the synonym list of $P$. tenuis Hantken. ${ }^{3}$ 
Pleurostomella nuttalli Cushman \& Siegfus, ${ }^{26} 1939$ (Pl. 1, fig. 13)

1939 Pleurostomella nuttalli Cushman \& Siegfus, ${ }^{26}$ p. 29, pl. 6, figs. 17, 18.

1975 Pleurostomella nuttalli; Proto Decima \& De Biase, ${ }^{20}$ p. 96 , pl. 3, fig. 8.

2000 Pleurostomella nuttalli; Sztrákos, ${ }^{6}$ p. 167, pl. 5, fig. 16.

2012 Pleurostomella nuttalli; Hayward et al., ${ }^{9}$ p. 231, pl. 38, figs. $7-14$.

Remarks: This late Cretaceous-middle Miocene cosmopolitan species has elongate test, loosely biserial, lobulate in outline and circular in cross-section, inflated final chamber, sutures distinct, wall hyaline smooth and finely perforated, aperture small oval opening of final chamber. After Hayward et al., ${ }^{9}$ this species was recorded from North Atlantic (early Eocene-late Oligocene; Sweden; Brotzen, 1936; Sites 548, 608), South Atlantic (Late Cretaceous; Sliter ${ }^{27}$ ), Indian Ocean (late Eocene-middle Miocene, Sites 758, 763), Southern Ocean (Late Cretaceous-late Oligocene; Sites 689, 690, 738, 744), North Pacific (latest Cretaceous-late Eocene, California, Cushman and Siegfus; ${ }^{26}$ Sites 865, 1211), equatorial Pacific Ocean (middle Eocene-middle Oligocene, Site 317); Southwest Pacific (late Eocene, New Zealand; GNS collections, U24/f270), Europe (Eocene, Italy and France). Hayward et al. (2012) noted that the paleo-bathymetric distribution of this species in present-day depth range of sites: lower bathyal-middle abyssal (1200-3600 m).

Pleurostomella obtusa Berthelin ${ }^{28}$ (P1. 1, fig. 14)

1880. Pleurostomella obtusa Berthelin, ${ }^{28}$ p. 29, pl. 1, fig. 9.

1989 Fursenkoina sp. Hulsbos et al., ${ }^{5}$ p. 270, pl. 3, fig. 6 .

1994. Pleurostomella obtusa; Bolli et al., ${ }^{17}$ p. 143, figs. 38.8-10.

Remarks: This Cretaceous-early Eocene species is distinguished by loose alternating biserial arrangement with rounded initial test and periphery. It was recorded from Albian of France, CenomanianConiacian of Trinidad. The figured early Eocene specimen of Hulsbos et al., ${ }^{5}$ from Norwegian Sea is closely related to P. obtusa.

Pleurostomella osmani Anan, ${ }^{29}$ n. sp. (Pl. 2, fig. 15)

Holotype: Plate 2, fig. 15.

Type locality: Abu Zenima section, Red Sea coast, west central Sinai, Egypt.

Type sample: sample 9, Sudr Chalk.

Age: late Maastrichtian, Abathomphalus mayaroensis Zone.

Depository: Department of Geology, Al-Azhar University-Gaza, Palestine (AZUGGD A48).

Etymology: In the honor of Dr. Osman Abdelghany, UAE University, in recognition for his contributions to the field of paleontology in Egypt and UAE.

Stratigraphy: The geological map of Abu Zenima area is shown in Figure 3, while the litho- and biostratigraphic section of Abu Zenima is presented in Figure 4. The oldest exposed rocks belong to the Maastrichtian Sudr Chalk (about $31 \mathrm{~m}$ ), overlain by $16 \mathrm{~m}$ thick sequence of calcareous shales and marls belonging to Paleocene Dakhla Shale, which rest unconformably on the Sudr Chalk. After Anan $^{30}$ twelve samples were collected from the chalk represent the top of the Maastrichtian Gansserina gansseri Zone (samples
1-5) and Abathomphalus mayaroensis Zone (samples 6-12). The topmost of the Sudr Formation is missing, due to recovered planktic foraminifera Plummerita hantkeninoides Zone. Based on the faunal assemblages, by Hewaidy ${ }^{31}$ named the northern Egypt "Bolivinoides province", while the central and southern Egypt "Orthokarstenia province". According to Anan ${ }^{29,30}$ the Maastrichtian of Abu Zenima section yield some diagnostic benthic foraminifera: Verneuilina aegyptiaca, Coryphostoma incrassata, Cibicidoides abudurbensis, Angulogavelinella avnimelechi, Gyroidinoides girardanus and Bolivinoides draco group.

Diagnosis: This new species has short test with rounded initial periphery. The initial chambers commonly are obscured, whereas others have a chamber arrangement varying from biserial to nearly uniserial. Chambers becoming slightly inflated. Sutures initially are indistinct, but later distinct and depressed. Wall calcareous and finely perforate. Aperture subterminal elliptical with overhanging hood, without apertural teeth.

Remarks: This species is distinguished by its short test than the other species of the genus, subterminal elliptical without toothed aperture.

\section{Pleurostomella paleocenica Cushman, ${ }^{32}$ (Pl. 2, fig. 16a-d)}

1947 Pleurostomella paleocenica Cushman, ${ }^{32}$ p. 86, pl. 18, figs. $14,15$.

1951 Pleurostomella paleocenica; Cushman, ${ }^{33}$ p. 45, pl. 12, figs. 31-33.

1975 Pleurostomella paleocenica, Berggren \& Aubert, ${ }^{34}$ p. 160, pl. 2, fig. 12.

1976 Pleurostomella paleocenica; Aubert \& Berggren, ${ }^{35}$ p. 426, pl. 7, fig. 5.

1982 Pleurostomella paleocenica; Proto Decima \& Bolli, ${ }^{20}$ p. 118. 12.

1994 Pleurostomella paleocenica; Bolli et al., ${ }^{17}$ p. 143, fig. 38. 11-

2003 Pleurostomella paleocenica; Ali, ${ }^{36}$ p. 123, pl. 7, fig. 19.

2005 Pleurostomella paleocenica; Sztrákos, ${ }^{37}$ p. 188, pl. 15, fig. 27.

2005 Pleurostomella paleocenica; Clemmensen \& Thomsen, ${ }^{38} \mathrm{p}$. 358, pl. 1, fig. 17.

Remarks: This Paleocene-early Eocene species has a wide geographic distribution from both sides of Atlantic Ocean (USA, Trinidad, France, Italy, North Sea), and also from North Africa (Tunisia and Egypt). It is characterized by its few chambers, distinctly inflated in the later portion, nearly as wide as high, increasing rapidly in size in the early portion, only slightly in the later portion, sutures distinct and later ones strongly on the upper part of the inner face of the last-formed chamber, wall smooth, aperture on the upper part of the inner face of the last-formed chamber, with a deeper reentrant toward the base of the opening. Hayward et al., ${ }^{9}$ treated this species as a junior synonym of $P$. alternans Schwager.

Pleurostomella plummerae Anan, ${ }^{39}$ n. sp. (Pl. 2, fig. 17)

1927 Pleurostomella alternans Plummer, ${ }^{12}$ p. 69, pl. 4, fig. 2b (non fig. 2a).

Holotype: Plate 2, fig. 17. 


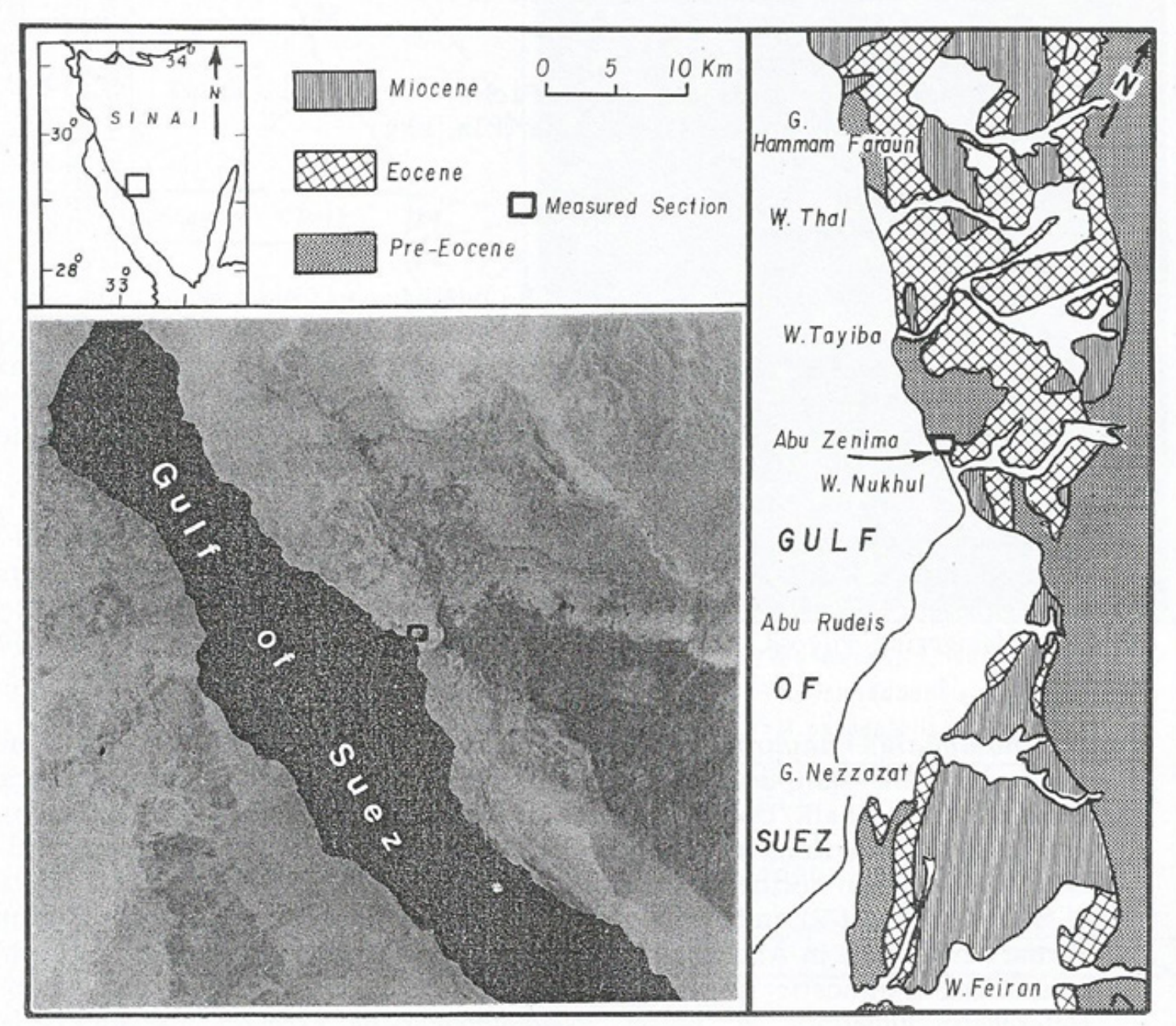

Figure 3 Geologic map of east Gulf of Suez, west central Sinai, Egypt and the location of Abu Zenima section, after Anan (1992).

Type locality: Midway Formation, Nicobar Island, Walker Museum Coll. 33007, Sta. 46 University of Chicago, USA.

Age: Paleocene.

Etymology: In the memory of the lateAmerican micropaleontologist H. J. Plummer.

Diagnosis: This Paleocene species has short and cuneate test The initial chambers commonly are obscured, whereas others have a chamber arrangement varying from biserial to nearly uniserial. Chambers becoming slightly inflated. Sutures initially are indistinct, but later distinct and depressed. Wall calcareous and finely perforate. Aperture terminal with overhanging hood with a deeper reentrant toward the base of the opening.

Remarks: This species is distinguished by its short test than the other species of the genus and oval aperture. It seems to be closely resemble with the Paleocene-early Eocene $P$. paleocenica Cushman and other new Maastrichtian species P. osmani Anan, but it differs from the first species it by its older stratigraphic state, and the younger stratigraphic state for the second species.

Pleurostomella subnodosa Reuss, ${ }^{2}$ (P1. 2, fig. 18a, b)
1860 Pleurostomella subnodosa Reuss, ${ }^{2}$ p. 204, pl. 8, fig. 2.

1946 Pleurostomella subnodosa; Cushman, ${ }^{15}$ p. 132, pl. 55, figs. $1-9$.

1956 Pleurostomella subnodosa; Said \& Kenawy, ${ }^{40}$ p. 145 , pl. 4 , fig. 26.

1968 Pleurostomella subnodosa; Sliter, ${ }^{27}$ p. 110, pl. 19, fig. 10.

1983 Pleurostomella subnodosa; Abdel-Kireem, ${ }^{41}$ p. 173.

1987 Pleurostomella subnodosa; Anan, ${ }^{42}$ p. 222, pl. 1, fig. 15.

1993 Pleurostomella subnodosa; Anan, ${ }^{43}$ p. 316, pl. 3, fig. 1.

2003 Pleurostomella subnodosa; Ali, ${ }^{36}$ p. 123, pl. pl. 7, fig. 21.

2011 Pleurostomella subnodosa; Mohan et al., ${ }^{8}$ p. 60, pl. 9, fig. 16.

2012 Pleurostomella subnodosa; Hayward et al., ${ }^{9}$ p. 231, pl. 38, figs. 20-27.

Remarks: This species slender, elongate and small to medium size smooth test, early biserial and staggered cuneate to uniserial at least in the latter portion, aperture hooded. It was originally described 
from the late Cretaceous of Europe, USA and Mexico, Maastrichtian of Abu Rawash section, west Cairo, Egypt by Anan, ${ }^{42}$ while in the Maastrichtian-Paleocene of Sinai (Egypt) by Said \& Kenawy ${ }^{40}$ and Paleocene from UAE by Anan. ${ }^{43}$ On the other hand, Plummer ${ }^{12}$ noted that the main differences between $P$. subnodosa Reuss and $P$. alternans Schwager lies in the character of the aperture, that of the former being simple and that of the latter toothed. P. subnodosa has 2 small apertural teeth by Sliter. ${ }^{27}$ Hayward et al.,${ }^{9}$ noted that P. subnodosa is more slender and usually smaller than $P$. alternans. Moreover, the paleobathymetric distribution of $P$. subnodosa in present-day depth range of sites: middle-upper abyssal (2000-4000 m); rare at lower bathyal (1200-2000 m).

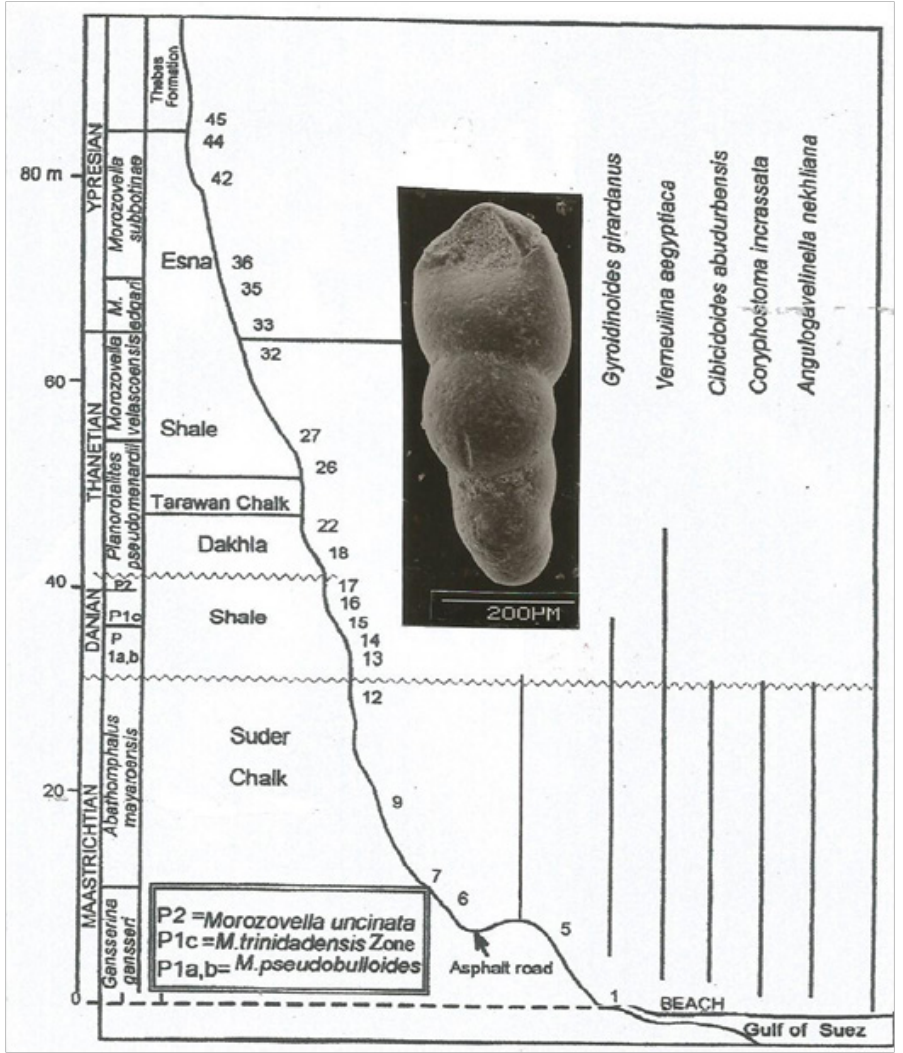

Figure 4 Schematic stratigraphic log of Abu Zenima section, west central Sinai of Egypt including the stratigraphic ranges of some diagnostic benthic foraminiferal Maastrichtian species (after Anan, 2004) with the stratigraphic range of the Pleurostomella osmani Anan, n. sp.

Pleurostomella velascoensis Cushman, ${ }^{16}$ (Pl. 2, fig. 19)

1926 Pleurostomella velascoensis Cushman, ${ }^{16}$ p. 590, pl. 16, fig. 4. 12.

1946 Pleurostomella velascoensis; Cushman, ${ }^{15}$ p. 133, pl. 55, fig. 15.

1994 Pleurostomella velascoensis; Bolli et al., ${ }^{17}$ p. 143, fig. 38. 14-

2003 Pleurostomella velascoensis; Ali, ${ }^{36}$ p. 123, pl. 7, fig. 20.

2005 Pleurostomella paleocenica; Sztrákos, ${ }^{37}$ p. 188, pl. 15, fig. 28.

Remarks: This Maastrichtian-early Eocene species has erected shape with three loosely biserial segment with terminal aperture and mainly a pointed base. Hayward et al. ${ }^{9}$ treated this species as a junior synonym of $P$. incrassata Hantken.

\section{Pleurostomella watersi Cushman, ${ }^{14}$ (Pl. 2, fig. 20)}

1933 Pleurostomella watersi Cushman, ${ }^{14}$ p. 63, pl. 63, figs. 11, 12. 23.

1946 Pleurostomella watersi; Cushman, ${ }^{15}$ p. 132, pl. 54, figs. 22,

Remarks: This late Cretaceous species has elongate and slender test, gradually increasing in breadth toward the apertural end and the axis somewhat twisted with lobulate sides. Its aperture large and high without tooth-like projections.

\section{Paleoenvironment, paleoecology paleobathymetry} and

a. Said \& Kenawy ${ }^{40}$ described and recorded more than two hundred benthic foraminiferal species from the Upper Cretaceous-Lower Tertiary strata of the two sections in northern Sinai, Egypt. These taxa shown an affinity with Midway-Type faunas (MTF) of American Gulf Coastal Plain, which indicate a similarity with fauna of Trinidad and Tampico Embayment of Mexico (about $70 \%$ ), together with a few forms from northern Europe. Abu Zenima section is also related to MTF.

b. Berggren $\&$ Aubert $^{34}$ noted that the lower Tertiary fauna in the northern part of Sinai Peninsula of Said \& Kenawy ${ }^{40}$ shows an affinity with the MTF.

c. Keller ${ }^{44}$ also noted that based on foraminiferal morphotype distributional patterns in the Negev-Sinai fauna across the K-T boundary have strong survivorship preference for species of epifaunal Habitat.

d. $A n a n^{43}$ noted that the Maastrichtian benthic foraminiferal species of Qarn El Barr section (UAE) and some other sections in Iraq, Jordan and Egypt are closest to the Maastrichtian fauna of Sinai, Egypt. The Maastrichtian chalk of Jiran El Ful section, west Cairo may indicative to open marine middle-outer neritic environment.

e. Issawi \& $\mathrm{Osman}^{45}$ noted that during the Cretaceous and Paleogene span of time, the land of Egypt witnessed many phases of transgressions and regressions of Tethys over a paleorelief (highs and lows of Syrian Arcs) by the syntectonic structures, which varied considerably from one place to other, and Lat. $28^{\circ} \mathrm{N}$ was considered by them to be detected the contact between the deep-water facies in the north and shallower in the south, but around Lat. $27^{\circ} \mathrm{N}\left(\mathrm{Anan}^{42}\right)$. In the Maastrichtian time, deep marine sediments were deposited in the north Egypt, whereas gradually becoming shallower and less thick southward to the coeval lithofacies predominated, as mentioned by other authors (i.e. Youssef, ${ }^{46} \operatorname{Anan}^{30,39,47,29}$ ).

f. Sztrákos ${ }^{37}$ noted that the Midway type species from the North Pyrenean trough (Aquitaine, France) were transported by the turbidite currents from the lower to middle neritic environments are frequent as well as Cretaceous reworked species.

g. Valchev ${ }^{21}$ noted that the taxa were recorded from the Paleocene of the coastal part of east Stara Planina (Eastern Bulgaria) belongs to Midway-type benthic foraminifera.

h. Anan ${ }^{48}$ noted that the probable environment for the northern Egypt 
(which represented by Abu Zenima section) is outer neritic-upper bathyal (200-400 m), which it deeper than the many locations in central Egypt, which are deposited in the middle-outer neritic (75$200 \mathrm{~m})$.
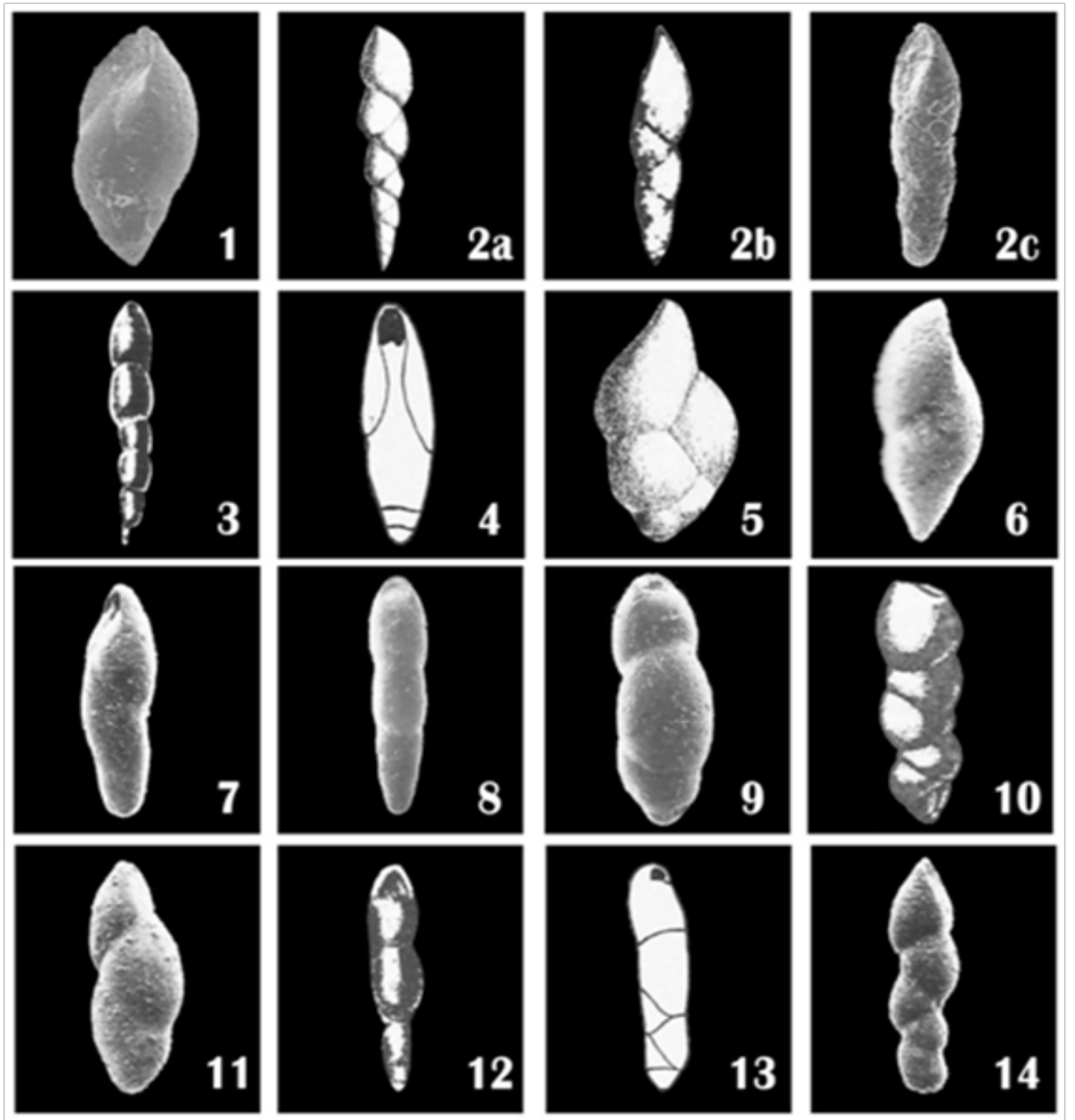

Plate I The species of the genus Pleurostomella: I: P. acuta (after Ozsvárt, $2007 \times 40$ ), 2a-c: P. alternans (a, aftre Schwager, I866 x 60; b, after Plummer, I927 x 60; c, after Ozsvárt, 2007 x 45), 3: P. austinana (after Cushman, 1946 x 80), 4: P. bellardii (after Sztrákos, 2000 x 60), 5: P. brevis (after Schwager, I866 x 50), 6: P. clavata (after Bolli et al, I $994 \times$ × 65), 7: P. cubensis (after Bolli et al, I 994 x 65), 8: P. eocaena (after Ozsvárt, 2007), 9: P. incrassata (after Ozsvárt, 2007), I 0: P. haquei Anan, n. sp. x 90, I I: P. naranjoensis (after Bolli et al, I994 × 65), I 2: P. nitida (after Cushman, I946 x II0), I 3: P. nuttalli (Sztrákos, 2000 × 50), I4: P. obtuse (after Bolli et al, $1994 \times 55$ ).

i. Hayward et al., ${ }^{13}$ recorded some species of the genus Pleurostomella from $700>3000 \mathrm{~m}$ in some deep-water sites from upper bathyal-middle abyssal of the Oceans. Hayward et al., ${ }^{9}$ presented more detailed valuable study on five families (Chrysalogoniidae, Glandulo-nodosariidae, Stilostomellidae, Ellipsoidinidae, Pleurostomellidae) of benthic foraminiferal species belonging to 30 genera (105 species) of cosmopolitan, mainly deep-sea $(600-4000 \mathrm{~m})$, became extinct during the late Pliocene-middle Pleistocene interval (3.6-0.13 Ma). These declines occurred in pulses mostly coinciding with glacial episodes of expansion of polar ice sheets, initially in Antarctica but during the mid-Pleistocene Climate Transition (MPT, 1.2-0.55 Ma) in the Arctic. ${ }^{49}$ The Cretaceous-Cenozoic Extinction Group (Ext. Gp.) species had an even spread of species durations between 5-85 myrs (except plectofrondiculariids), with mean species durations of 50 myrs (Pleurostomellidae). Cenozoic faunas are dominated by mostly long-lived species of just three genera: Strictocostella, Siphonodosaria and Pleurostomella. Moreover, the Last Global Extinction (LGE) and regional highest occurrence levels of Ext. Gp. species have considerable biostratigraphic value in providing rapid age assessments of Quaternary oceanic sediment where planktic foraminiferal age datum's are rare. 

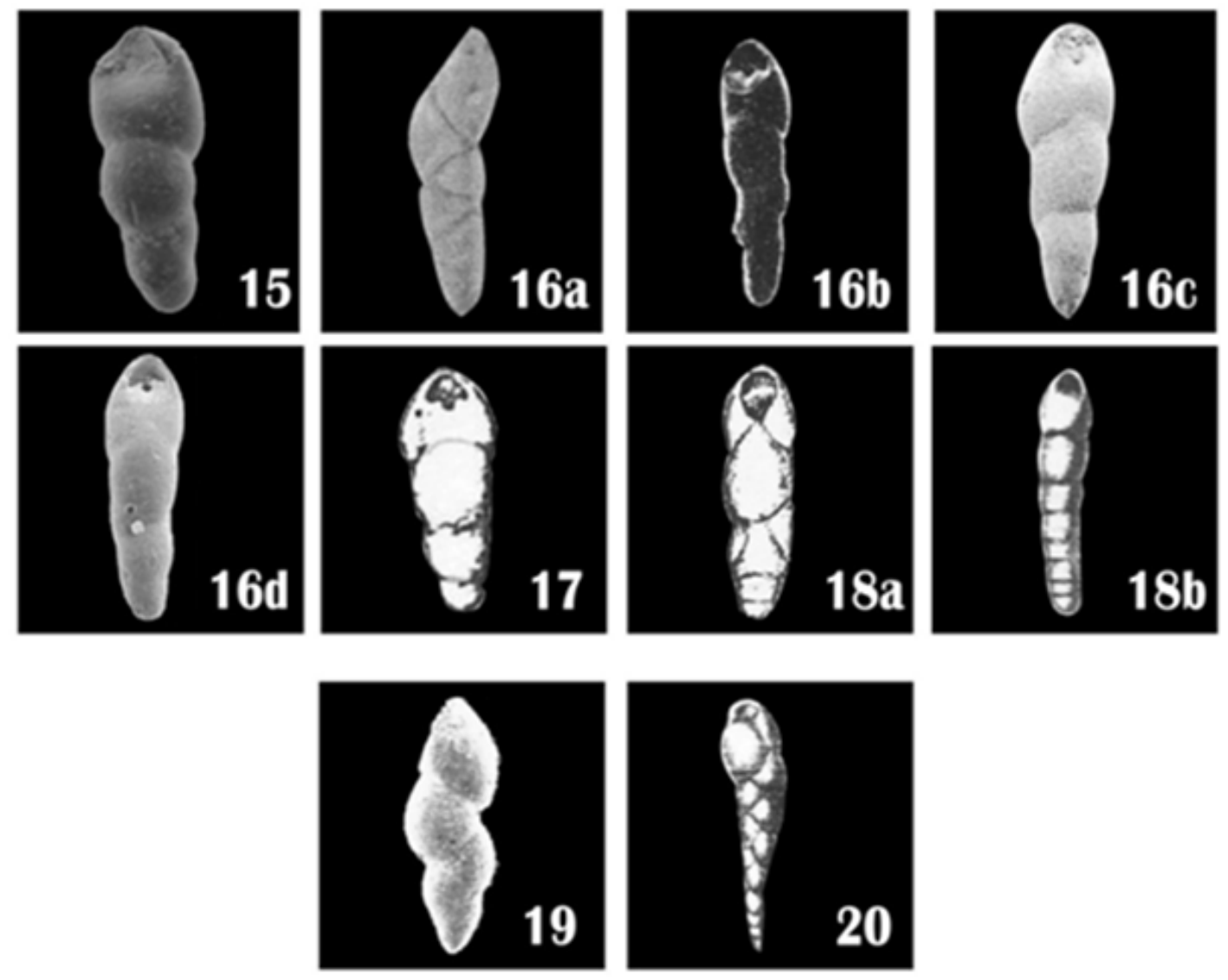

Plate 2 The species of the genus Pleurostomella: I5: P. osmani Anan, n. sp. x 30, 16a-d: P. paleocenica (a, after Cushman, 195I x 80; b, Berggren \& Aubert, 1975 × 80; c, after Ali, 2003 × 60; d, after Clemmensen \& Thomsen, 2005 × 35), I 7: P. plummerae Anan, n. sp. x I I0, I 8a, b: P. subnodosa (a, after Said \& Kenawy, 1956 × 65; b, after Sliter, 1968 × 40), 19: P. velascoensis (after Bolli et al, 1994 × 55; 20: P. watersi (after Cushman, $1946 \times 65$ ).

\section{Acknowledgments}

None.

\section{Conflicts of interest}

Author declares that there is no conflict of interest.

\section{References}

1. Loeblich AR, Tappan H. Foraminiferal genera and their classification. Van Nostrand Reinhold (VNR): New York; 1988. Part 1: 970 p., part 2: $847 \mathrm{p}$.

2. Reuss AE. The foraminifera of the Westphalian Chalk Formation. Session Reports of the Imperial Academy of Sciences in Vienna, Mathematical and Natural Sciences class. 1860;40:147-238.

3. Hantken M. The Clavulina Szaboi layers are in the Euganese and Sea Alps and the Cretaceous ùScaglia in Euganais. Hungarian scientific Academy. 1883;13(1):1-47.

4. Proto Decima F, De Biase R. Paleocene benthic foraminifera, of the lower and middle Eocene. In: Braga G, et al.: Paleocene and Eocene benthic foraminifers of the Possagno section. Schweizerische Paläontologische Abhandlungen. 1975;97:87-98.

5. Hulsbos RE. Eocene benthic foraminifers from the upper continental rise off New Jersey. Deep Sea Drilling Project. 1986;605(10):525-538.
6. Sztrákos K. Eocene foraminifers in the Adour Basin (Aquitaine, France): biostratigraphy and taxonomy. Revue de Micropaléontologie. 2000;43(1):71-172.

7. Ozsvărt P. Middle and Late Eocene benthic foraminiferal fauna from the Hungarian Paleogene Basin: systematics and paleoecology. Geologica Pannonica; 2007. 129 p.

8. Mohan K, Gupta AK, Bhaumik AK. Distribution of deep-sea benthic foraminifera in the Neogene of Blake Ridge, NW Atlantic Ocean. Journal of Micropalaeontology. 2011;30:33-74.

9. Hayward BW, Kawagata S, Sabaa A, et al. The last global extinction (Mid-Pleistocene) of deep-sea benthic foraminifera (Chrysalogoniidae, Ellipsoidinidae, Glandulonodosariidae, Plectofrondiculariidae, Pleurostomellidae, Stilostomellidae), their Late Cretaceous-Cenozoic history and taxonomy. Cushman Foundation for Foraminiferal Research Special Publication. 2012;43:1-408.

10. Alegret L, Thomas E. Benthic foraminifera across the Cretaceous/ Paleogene boundary in the Southern Ocean (ODP Site 690): Diversity, food and carbonate saturation. Marine Micropaleontology. 2013;105:40-51.

11. Schwager C. Fossile foraminiferen von Kar-Nicobar. Novara-Exped Geol Theil. 1866;2:187-268.

12. Plummer H. Foraminifera of the Midway Formation in Texas. Bulletin University of Texas. 1927;2644:3-206. 
13. Hayward BW, Kawagata S, Grenfell HR, et al. Last global extinction in the deep sea during the mid-Pleistocene climate transition. Paleoceanography. 2007;22(3):1-14.

14. Cushman JA. New American Cretaceous foraminifera. Contributions from the Cushman Laboratory for Foraminiferal Research. 1933;9(3):49-64.

15. Cushman JA. Upper Cretaceous Foraminifera of the Gulf Coastal Region of the United States and adjacent areas. USGS Numbered Series, Professional Paper, 206; 1946. 241 p.

16. Cushman JA. The foraminifera of the Velasco Shale of the Tampico Embayment. American Associaion of Petroleum Geology Bulletin $1926 ; 10(6): 581-612$

17. Bolli HM, Beckmann JP, Saunders JB. Benthic foraminiferal biostratigraphy of the south Caribbean region. Cambridge University; 1994. 1-408 p.

18. Cushman JA, Bermudez PJ. New genera and species of Foraminifera from the Eocene of Cuba. Cushman Foundation for Foraminiferal Research. 1936;12(2):27-38

19. Gümbel CW. Contributions to the foraminifera fauna of the North-Alpine Euclidean formations. K. bayer Akad Dep.1868;10(2):581-730 (also pp. $1-152)$.

20. Proto Decima F, Bolli HM. Paleocene smaller benthic foraminifera. In: Beckmann JP, et al. (Eds.): Micropaleontology and biostratigraphy of the Campanian to Paleocene of the Monte Giglio, Bergamo Province, Italy. Memorie de Scienze Geologiche: Padova; 1982. 114-120 p.

21. Valchev B. Midway-Type Benthic foraminifera from the Paleocene of the coastal part of East Stara Planina (Eastern Bulgaria). Family Textulariidae Ehrenberg, 1838 to Family Stilostomellidae Finlay, 1947. Annual of the University of Mining and Geology "St. Ivan Rilski". Geology and Geophysics. 2007;50(1):129-137.

22. Anan HS. Paleontology, paleoecology, paleobathymetry, paleogeography and stratigraphic significance of the latest Maastrichtian genus Plummerita in Duwi section, Egypt and Tethys. Revue de Paléobiologie. 2012;31(2):589-600.

23. Haque AFMM. Some middle to late Eocene smaller foraminifera from the Sor Rang, Quetta District, West Pakistan. Karachi: Govt. of Pakistan Press. 1960;2(2):9-57.

24. Bignot G. Middle Eocene benthic foraminifers from Holes 960 a and 960c, Central Atlantic Ocean. Proceedings of the Ocean Drilling Program, Scientific Results. 1998;159:433-444.

25. Morrow AL. Foraminifera and ostracoda from the Upper Cretaceous of Kansas. Journal of Paleontology. 1934;8(2):186-205.

26. Cushman JA, Siegfus SS. Some new and interesting foraminifera from the Kreyenhagen Shale of California. Contributions from the Cushman Laboratory for Foraminiferal Research. Sharona, Mass.: USA. $1939 ; 15(2): 23-33$.

27. Sliter WV. Upper Cretaceous foraminifera from Southern California and Northwestern Baja California, Mexico. University of Kansas Paleontological Contribution. 1968;49(7):1-141.

28. Berthelin G. Mémoire sur les foraminiféres fossiles de l'Etage Albien de Moncley (Doubs). Mémoires de la Société Géologique de France. 1880;31(5):1-84.

29. Anan HS. Paleontology, paleogeography and Paleoenvironment of the Paleocene benthic foraminiferal species of Plummer in the Tethys; a review. Journal of Tethys. 2017;5(3):272-296.

30. Anan HS. Maastrichtian to Ypresian stratigraphy of Abu Zenima section, west central Sinai, Egypt. Middle East Research Center, Ain Shams University, Earth Science Series. 1992;6:62-68
31. Hewaidy A. A proposed paleoecologic scheme for the Upper CretaceousLower Tertiary sequences in Egypt. Middle East Research Center, Ain Shams University, Earth Science Series: Cairo. 1997;11:159-168.

32. Cushman JA. Some new foraminifera from the Paleocene of the southern United States. Contributions from the Cushman Laboratory for Foraminiferal Research. 1947;23:81-86.

33. Cushman JA. Tertiary foraminifera of coastal Ecuador, Eocene. Journal of Paleontology. 1951;25(2):129-164.

34. Berggren WA, Aubert J. Paleocene benthonic foraminiferal biostratigraphy, paleobiogeography and paleoecology of Atlantic-Tethyan regions: Midway-type fauna. Palaeogeography, Palaeoclimatology, Palaeoecology. 1975;18(2):73-192.

35. Aubert J, Berggren WA. Paleocene benthonic foraminiferal biostratigraphy and paleoecology of Tunisia. Bulletin du Centre de Recherches Pau-SNPA. 1976;10(2):379-469.

36. Ali MY. Micropaleontological and stratigraphical analyses of the Late Cretaceous/Early Tertiary succession of the Southern Nile Valley (Egypt). Dissertation submitted to the Faculty of Geosciences of the Ruhr University Bochum; 2003. 197 p.

37. Sztrákos K. Paleocene and lowest Eocene foraminifera from the north Pyrenean trouph (Aquitaine, France). Revue de Micropaléontologie. 2005;48(3):175-236.

38. Clemmensen A, Thomsen E. Paleoenvironmental changes across the Danian-Selandian boundary in the North Sea Basin. Palaeogeography Palaeoclimatology, Palaeoecology. 2005;219(3-4):351-394.

39. Anan HS. Contribution to the stratigraphy and paleobiogeography of some diagnostic Upper Cretaceous and Paleogene Foraminifera. Neues Jahrbuch für Geologie und Paläontologie. 1994;5:257-266.

40. Said R, Kenawy A. Upper Cretaceous and Lower Tertiary foraminifera from northern Sinai, Egypt. Micropaleontology. 1956;2(2):105-173.

41. Abdel-Kireem MR. A study of the paleoecology and bathymetry of the foraminiferal assemblages of the Shiranish Formation (Upper Cretaceous), northeastern Iraq. Palaeogeography, Palaeoclimatology, Palaeoecology. 1983;43(1-2):169-180.

42. Anan HS. Biostratigraphy and paleoecology of Maastrichtian and Paleocene benthonic foraminifera from Jiran El Ful section, Abu Rawash area, Egypt. Middle East Research Center, Ain Shams University, Earth Science Series, Cairo. 1987;1:207-227.

43. Anan HS. Maastrichtian-Paleocene micropaleontology and biostratigraphy of Qarn El Barr section, Al Dhayd area, United Arab Emirates. Al-Azhar Bulletin of Science, Al-Azhar University, Cairo. 1993;4(2):639-670.

44. Keller G. Paleoecological response of Tethyan benthic foraminifera to the Cretaceous-Tertiary boundary transition. In: Takayanagi, Y. \& Saito, T. (Eds.), Studies in benthic Foraminifera. Tokai University Press: Tokyo; 1992. 77-91 p

45. Issawi B, Osman R. Upper Cretaceous-Lower Tertiary platform-ramp environment in northern Egypt. 5th International Conference on the Geology of the Arab World, Cairo University; 2000. 1289-1308 p.

46. Youssef MI. Upper Cretaceous rocks in Kosseir area. Bulletin Institute Desert d'Egypt. 1957;7(2):35-54

47. Anan HS. A lineage phylogeny for some Maastrichtian to Ypresian benthic foraminifera in Egypt. Egyptian Journal of Paleontology. 2004;4:39-57.

48. Anan HS. Additional to the Maastrichtian foraminifera of the Middle East. Revue de Paléobiologie. 2011;30(1):295-311.

49. Weinholz P, Lutze GF. The Stilostomella Extinction. Proceedings of the Ocean Drilling Program, Scientific Results. 1989;108:113-117. 